Article

\title{
'Forced Car Ownership' in the UK and Germany: Socio-Spatial Patterns and Potential Economic Stress Impacts
}

\author{
Giulio Mattioli ${ }^{1,2}$ \\ ${ }^{1}$ Sustainability Research Institute, University of Leeds, Leeds, LS2 9JT, UK; E-Mail: g.mattioli@leeds.ac.uk \\ 2 Institute for Transport Studies, University of Leeds, Leeds, LS2 9JT, UK
}

Submitted: 28 June 2017 | Accepted: 20 September 2017 | Published: 28 December 2017

\begin{abstract}
The notion of 'forced car ownership' (FCO), born out of transport research on UK rural areas, is used to define households who own cars despite limited economic resources. FCO is thought to result in households cutting expenditure on other necessities and/or reducing travel activity to the bare minimum, both of which may result in social exclusion. Social exclusion research, on the other hand, has paid much attention to 'material deprivation', i.e., the economic strain and enforced lack of durable goods arising from low income. However, the FCO phenomenon suggests that, among households with limited resources, the enforced possession and use of a durable good can be the cause of material deprivation, economic stress and vulnerability to fuel price increases. In this study, we use 2012 EU 'Income and Living Conditions' data (EU-SILC) to shed light on FCO in two European countries (UK and Germany). Through secondary data analysis we are able to show: the social and spatial patterns of FCO; key differences between FCO and 'car deprived' households; the intensity of social exclusion, material deprivation, and economic strain among FCO households; and overlaps between FCO and economic stress in other life domains (domestic fuel poverty, housing cost overburden). The results also show contrasting spatial patterns of FCO in Germany (higher incidence in rural areas) and UK (similar incidence in urban and rural areas), which can be explained in light of the different socio-spatial configurations prevalent in the two countries. We conclude by discussing implications for future research and policy-making.
\end{abstract}

\section{Keywords}

car use; economic stress; forced car ownership; material deprivation; social exclusion; transport

\section{Issue}

This article is part of the issue "Regional and Urban Mobility: Contribution to Social Inclusion", edited by Janet Stanley (University of Melbourne, Australia) and John Stanley (University of Sydney, Australia).

(C) 2017 by the author; licensee Cogitatio (Lisbon, Portugal). This article is licensed under a Creative Commons Attribution 4.0 International License (CC BY).

\section{Introduction}

Since the early 2000s, there has been increasing research on the connections between transport and social exclusion, notably in the UK (Lucas, 2012; Ricci, Parkhurst, \& Jain, 2016; SEU, 2003) and Australia (Currie, 2011; Currie, Stanley, \& Stanley, 2007), but more recently also in other countries such as Germany (BMVBS, 2012). Most of this research has focused on those who are excluded from car ownership and use in developed countries, where levels of car dependence have increased dramatically during the 20th century (Pooley, 2016). Studies have often focused on suburban, periurban and rural areas, where modal alternatives to the pri- vate car are less available. 'Recurring characters' in transport and social exclusion research include low-income households, older and younger people, women, immigrants and ethnic minorities, people with a disability, and people in unemployment (which collectively form a considerable proportion of the population). All of these groups are less likely to drive cars than the average of the population for reasons including, but not limited to, the affordability of owning and operating vehicles. Interestingly, these are also the groups that are generally identified as more at risk of social exclusion, suggesting the existence of strong linkages between lack of car ownership, transport disadvantage and broader exclusionary processes. 
Comparatively little attention has been paid to the forms of transport disadvantage experienced by car users in car dependent societies, where high levels of car use may be required for human needs satisfaction (Mattioli, 2016). A number of studies (reviewed in the next section) have employed the notion of 'forced car ownership' (FCO) to refer to households who, despite limited economic resources, own and use cars as the only viable way of accessing essential services and opportunities. FCO has been linked to a range of negative consequences, including reduced travel activity, cuts to other parts of the household budget and vulnerability to fuel price increases.

This article explores social and spatial patterns of FCO in the UK and Germany. EU survey data allows us to compare the two countries based on nationallyrepresentative, harmonized data, as well as to investigate the links between FCO and social exclusion, material deprivation and economic stress indicators. The article advances previous research in three ways. First, with few exceptions (e.g., Currie, 2011) to date, transport and social exclusion research has engaged little with the quantitative measurement of social exclusion and its sub-dimensions at the household or individual level (although place-based indicators have been developedsee e.g., Curl, Nelson, \& Anable, 2011). Arguably, quantitative evidence on transport disadvantage is crucial to persuade policy makers of the relevance of the problem, and can inform the development of targeted policy measures. Second, perhaps because of the lack of harmonized data, quantitative studies comparing transport disadvantage across different countries are still relatively rare. Finally, there is only limited quantitative evidence on the financial sacrifices and economic stress experienced by forced car owners.

Overall, this article aims to demonstrate that the EUSILC dataset (described in Section 3) is a valuable and currently untapped resource for the quantitative study of FCO and 'car deprivation' in an internationally comparative perspective. By demonstrating how these concepts can be operationalized using EU-SILC data, it opens up a number of interesting directions for future research, as discussed in the conclusions.

The article is structured as follows: Section 2 briefly reviews existing literature on FCO, Section 3 introduces the data source, the case study countries and the data analytical approach, Section 4 presents the findings, which are discussed in Section 5 along with policy implications and directions for future research.

\section{Background}

The review in this section focuses on empirical studies which have adopted the notion of FCO, and notably on those providing quantitative evidence on its incidence, socio-spatial patterning, and the households' economic stress situation. We also highlight how the notion of FCO has been operationalised in previous research. The goal is to provide a point of reference against which to compare the results of this study.

Currie and Senbergs (2007) find early occurrences of the term 'forced car ownership' in Jones (1987) and Banister (1994), both of which use it to refer to UK rural areas. The first article to quantify the incidence of FCO is Currie and Senbergs' study of Melbourne (2007). Based on 2001 census data, the authors define FCO as households with 'low incomes' (lowest quartile), and 'high car ownership' (two or more cars). They find that $5.7 \%$ of households in Outer Melbourne can be considered FCO, as compared to only $1.9 \%$ in the inner city. Multivariate analysis of spatial data shows that the share of FCO is negatively related to public transport supply and positively related to distance to activity centres, with opposite effects for the proportion of low income households with no cars.

Based on descriptive analysis of travel survey data for 1996 (and focusing on Outer Melbourne residents only), Currie and Senbergs (2007) suggest that FCO can be typified as "young families with children with a high share of home keepers" (p. 19). They are also overrepresented among households with mortgages and in detached houses. This contrasts with the profile of low income households without a car, which the authors typify as "older (people) living in a single person household with a high share of rented accommodation on a pension" (p. 21). FCO also make the vast majority of their trips by car, make less trips per day and travel shorter distances than other multi-car households in Outer Melbourne, but more than low income households in other parts of Melbourne. The authors take this evidence as suggestive of high levels of expenditure on car use relative to incomes.

Currie and Delbosc (2011) have further investigated the lived experiences of low-income households in Outer Melbourne, based on bespoke survey data. They find that FCO have lower levels of transport difficulties and social exclusion (measured based on a bespoke scale covering income poverty, unemployment and social participation), but higher levels of financial stress than lowincome households without a car.

Relevant to this study, a government-commissioned study (BMVBS, 2012) has investigated FCO in Germany based on 2008 national travel data. It defined FCO as households with: i) at least one car, ii) income below the poverty line, and iii) self-assessed good accessibility to shops and/or workplace by car, but not by alternative modes. The results show that $3 \%$ of German households are FCO, with the incidence varying dramatically between large cities $(0.9 \%)$ and small rural municipalities (5.7\%).

Curl, Clark and Kearns (in press) have investigated FCO in deprived communities in Glasgow (UK), based on bespoke survey data. They define FCO as households who i) own at least one car and ii) report difficulties to afford at least one of five items (rent, mortgage, household maintenance, energy bills, and food). The findings show that $8.5 \%$ of the sample can be defined as FCO in 2011, 
with an overrepresentation of households with two or more children.

To conclude this review it must be noted that the use of the term 'forced car ownership' is controversial. In the literature, a number of alternative terms are used to refer to households struggling to afford the running costs of motoring, including, e.g., 'transport poverty' (Gleeson \& Randolph, 2002), 'fuel poverty in the transport sector' (Berry, Jouffe, Coulombel, \& Guivarch, 2016) and 'carrelated economic stress' (Mattioli \& Colleoni, 2016). Mattioli (2013) argues that much broader sections of the population are 'forced' into car ownership, and that what is distinctive about 'FCO' is rather that car ownership results in economic stress for the affected households. On the other hand, Currie and colleagues have criticized the notion of FCO for being value-laden and misleading, as it downplays the agency of households who have often made a conscious decision to own vehicles and live in car-dependent areas, in exchange for benefits such as access to affordable housing (Currie \& Delbosc, 2011; Currie \& Senbergs, 2007). Other authors, however, argue that low-income households have limited choice when it comes to residential location, due to lower purchasing power, but also to other factors such as e.g., reliance on local social networks (Belton Chevallier, Fol, MotteBaumvol, \& Jouffe, in press; Curl et al., in press; Mullen \& Marsden, in press; Scheiner, in press). In a nutshell, FCO appears to result from a complex mix of structural constraints and household agency, with an ongoing debate on their respective importance.

While we acknowledge the limitations of the FCO terminology, in this article we use the term to emphasize continuity with previous research, and the fact that our empirical definition is based on data on car ownership, rather than car use and related expenditure (see Section 3.3.1 below).

\section{Methodology}

\subsection{Data}

Since 2004, the EU-SILC (European Union Statistics on Income and Living Conditions) survey is conducted every year in the member states, and is the data source for the official EU social indicators. EU-SILC is a 'harmonized' survey, i.e., different member states use different survey instruments to collect the data, but follow a common blueprint set by Eurostat, which guarantees the comparability of resulting data. It covers a range of topics including income, housing expenditure, labour market situation and material deprivation. While there is no specific module on transport in EU-SILC, some information is collected as it is relevant to other agendas. In this article, we use the 2012 wave as it includes information on accessibility to public transport services, which is key for our analysis. The sample we use is representative of the population of private households residing in the UK and Germany, although for cost reasons addresses from the
Isles of Scilly were excluded from the UK sample frame, and addresses north of the Caledonian Canal in Scotland were under-sampled (note that these areas account for less than $2 \%$ of the UK population). The sample size is 10,175 households $(18,336$ individuals) in the UK, and 13,145 households (23,587 individuals) in Germany. In both countries, all household members aged 16 or more were personally interviewed. Weights have been applied to adjust for probability of selection, non-response, and to reproduce sample population characteristics.

\subsection{Case Studies}

Our analysis focuses on Germany and the UK. Both are large and rich Northern EU countries with comparable levels of car ownership (as illustrated in Section 4.1), and have seen similar trends towards suburbanisation and car dependence in the 20th century (Mattioli, 2013), although not as dramatically as New-World English-speaking countries such as Australia and the US. There is, however, a number of institutional and regulatory differences between the two countries which must be taken into account when interpreting the findings.

The German model of capitalism is seen as more conducive to the provision of public goods than the liberal model of English-speaking countries (Logemann, 2012). This is particularly apparent when comparing the regulatory setting of public transport in Germany and the UK. In the 1980s, the UK government implemented the privatisation and quantity deregulation of local bus services outside of London, and this has resulted in substantial reductions in patronage levels and public subsidies, while fares have increased (Mees, 2010; Preston \& Almutairi, 2013). This may have added to FCO pressures by reducing the quality of modal alternatives to the car. By contrast, in Germany the public sector retains control of quality and quantity of the service and subsidises operating costs to a larger extent than in the UK (Dziekan, 2011). The German model of 'transport associations' has also been successful in providing integrated and seamless public transport services in city-regions (Mees, 2010; Pucher \& Kurth, 1996). Finally, as a result of investment in public transport infrastructure, German cities of more than 50,000 inhabitants typically have networks of buses, tramways and regional trains, which compares favourably with the UK (Dziekan, 2011; Shaw \& Docherty, 2014). On the other hand, German policies to contain urban sprawl appear to have been less successful than England's (Baing, 2010), which may have increased the need for car ownership and use.

\subsection{Approach}

\subsubsection{A Material-Deprivation-Based Indicator of FCO}

A composite indicator of 'material deprivation' is used by the EU to measure levels of absolute poverty (Fusco, Guio, \& Marlier, 2013), and is included in EU-SILC. It is 
based on the self-reported ability to afford the following necessities:

1. to face unexpected expenses (of an amount equivalent to the monthly poverty line in the respondent's country);

2. one week annual holiday away from home;

3. to pay for arrears (for mortgage or rent, utility bills or hire purchase instalments);

4. a meal with meat, chicken or fish (or vegetarian equivalent) every second day;

5. to keep home adequately warm;

6. to have a washing machine;

7. to have a colour TV;

8. to have a telephone (fixed landline or mobile);

9. to have a car/van for private use.

Households who cannot afford at least three of the nine items are considered to be in 'material deprivation' ('severe' material deprivation if four items or more). The scale includes two sub-components: 'economic strain' (items 1-5) and 'enforced lack of durables' (items 6-9). In the case of durable goods, respondents have to select one of three alternatives: 1) household owns good; 2) household would like to have it but cannot afford it; and 3) household does not own good for other reasons e.g., does not want it or need it. Therefore, it is impossible for a household to report that they own, for example, a car but they cannot afford it.

It is important to note that the selection of nine material deprivation items was validated in a EU-wide survey study which showed that: 1 ) all items are considered as necessary "to have a decent standard of living" by a majority of the EU population; and 2) within countries, there is a social consensus across social groups (e.g., social strata, age bands) on the fact that these constitute necessities (for more detail see Fusco et al., 2013). Therefore, the material deprivation indicator is meant to "capture a situation of exclusion from a minimum acceptable way of life due to lack of resources" (Fusco et al., 2013, p. 48).

In our analysis, we exploit information on car ownership, material deprivation and reasons for non-car ownership, drawn from the nine variables above, to identify four groups:

- Forced Car Owners (FCO): households who own at least a car and are materially deprived. This definition is similar to Curl et al.'s (in press), but is based on the official EU indicator of absolute poverty. We assume that these households trade-off (at least potentially) motoring expenditure against expenditure in other essential areas;

- Other Car Owners (OCO): households who own at least a car and are not materially deprived;

- Car Deprived (CD): households who do not own cars because they 'cannot afford it';

- Other Non-Car Owners (ONCO): households who do not own cars for 'other reasons'.
In Section 4.1 we compare the four groups by means of descriptive statistics and multivariate logistic regression. We use two sets of regression models to show how FCO differ from the average of the population, as well as from 'car deprived' households. This is particularly important since, as discussed in Section 1, people who cannot afford cars have to date attracted most of the attention in transport and social exclusion research.

\subsubsection{Descriptive Variables}

In Section 4.1, we use two variables to describe the residential location and public transport accessibility of households. A harmonized 'degree of urbanisation' variable is provided in EU-SILC, allowing the comparison of different member states. The variable classifies LAU2s (Local Administrative Units Level 2, corresponding to municipalities or equivalent units) in three categories, based on grid cells of $1 \mathrm{~km}^{2}$ (Eurostat, n.d., pp. 3-4):

- densely populated areas (cities): at least $50 \%$ of the population lives in 'high density clusters' (i.e., continuous grid cells with a density of at least 1,500 inhabitants per $\mathrm{km}^{2}$ and a minimum population of 50,000);

- intermediated areas (towns and suburbs): less than $50 \%$ of the population lives in rural grid cells and less than $50 \%$ lives in high density clusters;

- thinly populated areas (rural): more than $50 \%$ of the population lives in grid cells outside of 'urban clusters' (i.e., clusters of contiguous grid cells of $1 \mathrm{~km}^{2}$ with a density of at least 300 inhabitants per $\mathrm{km}^{2}$ and a minimum population of 5,000 ).

In the 2012 wave, respondents were asked to rate the 'accessibility of public transport'. Accessibility was defined in terms of physical and technical access and appropriateness of timetables, and respondents were instructed not to take into account quality, price and similar aspects. Therefore, the resulting variable is best interpreted as a (self-reported) measure of access to public transport, rather than as an indicator of the accessibility to services and opportunities provided by public transport.

In Section 4.2, we profile FCO and other groups based on a range of indicators of social exclusion and economic stress drawn from EU-SILC. Definitions are provided below (unless otherwise stated the source is Eurostat, 2017).

The main EU social policy indicator is the number of people 'at risk of poverty and social exclusion' (AROPE). A household is considered AROPE if any of the following applies:

- income poverty: equivalised net income (after social transfers) is less than $60 \%$ of the national median;

- 'severe' material deprivation;

- 'very low' work intensity (WI). WI is defined as the ratio between the number of 'worked' and 'work- 
able' months, in the 12 months preceding the interview, for working age members. It ranges between 0 ('jobless household') and 1, with values lower than 0.5 defined as 'low', and 'very low' if less than 0.2 .

While no official definition of 'in-work poverty' at the household level is provided by the EU (Ponthieux, 2010), in our analysis we define the 'working poor' as incomepoor households with non-zero work intensity.

Recent research on transport affordability and carrelated economic stress has highlighted the links and overlaps with issues of housing and domestic energy affordability (see, e.g., Cao \& Hickman, in press; Li, Dodson, \& Sipe, in press; Mattioli, 2015; Mattioli, Lucas, \& Marsden, 2017; Ortar, in press). In our analysis, we explore the relationships between these different forms of economic stress, based on two indicators. EU households are considered to be in 'housing cost overburden' if total housing costs (net of housing allowances) represent more than $40 \%$ of disposable income (net of housing allowances). 'Fuel poverty' is a term used in the UK and the EU to refer to the inability to afford adequate domestic energy services, with a notable focus on heating. Drawing on Thomson and Snell (2013), we define fuel poor households as those reporting at least one of the following: 1) 'cannot afford to keep home adequately warm', 2) arrears on utility bills in the last 12 months, and 3) presence of leaks, damp or rot in the dwelling.

\section{Results}

\subsection{Social and Spatial Correlates of FCO}

In 2012, 6.7\% of UK households and 5.1\% in Germany were FCO (corresponding to roughly 600 unweighted observations in both national samples). The total share of households with cars was at very similar levels (77-78\%) in the two countries. Overall, the distribution of households across the four groups (first row in Table 1) was also remarkably similar.

Table 1 shows how the prevalence of FCO and the three other groups varies across different sectors of the population. The row variables in Table 1 correspond to the independent variables used in the regression models in Table 2 below. The variables cover socio-demographic (household composition, age, gender, and immigrant status), economic (income and work intensity) and spatial factors (degree of urbanisation, accessibility to public transport), as well as mobility difficulties (operationalised as presence of household members with limitations in activities because of health problems). Previous research has found these factors to be associated with low-income, car ownership and use (e.g., Lucas, Bates, Moore, \& Carrasco, 2016; Mattioli, 2014; Stokes \& Lucas, 2011). Previous studies have also suggested a relationship between FCO and access to (detached) home ownership, often backed up by mortgages (see Section 1;
Dodson \& Sipe, 2008; Walks, 2015). To investigate these relationships we include tenure and type of dwelling in our analysis.

The descriptive results in Table 1 show that in both countries FCO are overrepresented among households with children, in the middle age bands (40s and 50s), in the bottom 40 percent of the income distribution, as well as among households with mobility difficulties and home-renters. FCO is high among jobless households but also among households with low (and, in the UK, medium) work intensity.

With regard to differences between countries, Table 1 shows that FCO are overrepresented among large households and immigrant households in the UK, but not in Germany. Conversely, in Germany FCO are overrepresented in thinly populated areas and among households reporting difficult access to public transport, while no such difference is observed in the UK-in fact, the incidence rate of FCO is virtually the same across different type of areas.

'Car deprived' households account for approximately $11 \%$ of households in both countries, and have both similarities and differences with FCO (Table 1). CD are similarly overrepresented in the bottom $40 \%$ of the income distribution, among jobless and low-work-intensity households, as well as among tenants and households with mobility difficulties. However, CD differ from FCO in a number of respects: they are overrepresented among single-person and young households, as well as in densely populated areas and among those reporting easy access to public transport. In Germany, they are overrepresented among households without a working age member. Also, in both countries they are strongly overrepresented among households living in flats-whereas the incidence of FCO is relatively similar across types of dwelling.

The logistic regression Models 1 and 3 model the probability of belonging to FCO, as opposed to any other group in our classification (Table 2 ). The results broadly confirm the findings in Table 1, with some qualification. In both countries, there is no statistically significant effect of household size, once other factors are controlled for. The presence of children is significantly associated with FCO in the UK, but not in Germany. Also, after controlling for confounding effects, households with low working intensity are more likely to be FCO than both jobless households and households with a higher WI factor. In both countries, there is a statistically significant net effect of tenure, as outright owners have the lowest (and private market tenants the highest) probability of FCO. Finally, the models show a significant net association between FCO and type of dwelling, with the probability highest for households living in semi-detached housing (in the UK) or small blocks of flats (in Germany).

In Germany, households without working age members are significantly less likely than other households to be FCO, while households with a female 'household respondent' are more likely once other factors are controlled for. 
COGITATIO

Table 1. Distribution of 'car ownership/material deprivation' indicator in different social groups. Percentage values [unweighted sample size in square brackets] (EU-SILC, 2012).

\begin{tabular}{|c|c|c|c|c|c|c|c|c|c|c|c|c|c|}
\hline & & \multicolumn{5}{|c|}{$U K$} & \multicolumn{7}{|c|}{ Germany } \\
\hline & & FCO & OCO & $C D$ & ONCO & Total & [n] & FCO & OCO & CD & ONCO & Total & [n] \\
\hline & TOTAL & 6.7 & 70.2 & 10.6 & 12.5 & 100 & [10095] & 5.1 & 72.8 & 11.5 & 10.6 & 100 & [12982] \\
\hline \multirow[t]{4}{*}{ Household size } & 1 & 5 & 52 & 17 & 26 & 100 & [2917] & 5 & 53 & 22 & 20 & 100 & [3770] \\
\hline & 2 & 5 & 79 & 8 & 8 & 100 & [3604] & 4 & 83 & 6 & 7 & 100 & [5096] \\
\hline & 3 & 9 & 75 & 9 & 7 & 100 & [1476] & 6 & 87 & 4 & (3) & 100 & [1598] \\
\hline & $4+$ & 11 & 78 & 7 & 4 & 100 & [1846] & 5 & 91 & (2) & (2) & 100 & [1715] \\
\hline \multirow[t]{2}{*}{ Minor children } & 0 & 5 & 70 & 10 & 15 & 100 & [6785] & 4 & 70 & 13 & 13 & 100 & [9498] \\
\hline & $1+$ & 11 & 71 & 12 & 6 & 100 & [3058] & 7 & 83 & 6 & 4 & 100 & [2681] \\
\hline \multirow[t]{5}{*}{ Work intensity } & Jobless household (0) & 13 & 27 & 36 & 24 & 100 & [1026] & 11 & 30 & 42 & 17 & 100 & [879] \\
\hline & Low WI (0-0.5) & 18 & 47 & 22 & 13 & 100 & [530] & 12 & 63 & 16 & (9) & 100 & [533] \\
\hline & Medium WI (0.5-1) & 9 & 80 & 6 & 5 & 100 & [2236] & 5 & 85 & 6 & 4 & 100 & [3571] \\
\hline & High WI (1) & 5 & 82 & 5 & 8 & 100 & [2772] & 4 & 79 & 6 & 11 & 100 & [2925] \\
\hline & No working age member & 3 & 69 & 9 & 19 & 100 & [3279] & 3 & 69 & 13 & 15 & 100 & [4271] \\
\hline \multirow[t]{6}{*}{ Age of $\mathrm{HR}^{*}$} & $16-29^{+}$ & 7 & 51 & 27 & 15 & 100 & [696] & (5) & 57 & 21 & 17 & 100 & {$[574]$} \\
\hline & $30-39$ & 9 & 70 & 11 & 10 & 100 & [1556] & 5 & 73 & 12 & 10 & 100 & [1392] \\
\hline & $40-49$ & 9 & 72 & 10 & 9 & 100 & [1980] & 6 & 76 & 10 & 8 & 100 & [2490] \\
\hline & $50-59$ & 9 & 77 & 6 & 8 & 100 & [1701] & 6 & 74 & 12 & 8 & 100 & [2563] \\
\hline & $60-69$ & 5 & 79 & 7 & 9 & 100 & [1720] & 4 & 73 & 14 & 9 & 100 & [2536] \\
\hline & $70+$ & $(2)$ & 67 & 9 & 22 & 100 & [2190] & 3 & 73 & 9 & 15 & 100 & [2624] \\
\hline \multirow[t]{2}{*}{ Health-related activity limitation } & No members & 5 & 77 & 9 & 9 & 100 & [6432] & 4 & 76 & 9 & 11 & 100 & {$[6613]$} \\
\hline & $1+$ & 11 & 58 & 13 & 18 & 100 & [3411] & 7 & 68 & 15 & 10 & 100 & [5566] \\
\hline \multirow[t]{2}{*}{ Immigration status of HR } & No immigration & 6 & 73 & 9 & 12 & 100 & [8770] & 5 & 73 & 11 & 11 & 100 & [11443] \\
\hline & Immigration & 10 & 58 & 16 & 16 & 100 & [1073] & (5) & 69 & 15 & 11 & 100 & [736] \\
\hline \multirow[t]{2}{*}{ Sex of HR } & Male & 6 & 77 & 8 & 9 & 100 & [5438] & 4 & 80 & 8 & 8 & 100 & [7819] \\
\hline & Female & 7 & 62 & 14 & 17 & 100 & [4405] & 6 & 62 & 17 & 15 & 100 & [4360] \\
\hline \multirow[t]{4}{*}{ Equivalised disposable income quintile } & Lowest & 12 & 47 & 24 & 17 & 100 & [2032] & 10 & 37 & 36 & 17 & 100 & [1905] \\
\hline & Second & 11 & 58 & 14 & 17 & 100 & [2092] & 8 & 65 & 14 & 13 & 100 & [2391] \\
\hline & Third & 7 & 71 & 8 & 14 & 100 & [2020] & 4 & 81 & 5 & 10 & 100 & [2609] \\
\hline & Fourth or highest & 2 & 89 & 2 & 7 & 100 & [3699] & 2 & 89 & 1 & 8 & 100 & [5274] \\
\hline
\end{tabular}


Table 1. Distribution of 'car ownership/material deprivation' indicator in different social groups. Percentage values [unweighted sample size in square brackets] (EU-SILC, 2012). (Cont.)

\begin{tabular}{|c|c|c|c|c|c|c|c|c|c|c|c|c|c|}
\hline & & \multicolumn{5}{|c|}{ UK } & \multicolumn{7}{|c|}{ Germany } \\
\hline & & FCO & OCO & CD & ONCO & Total & [n] & FCO & OCO & CD & ONCO & Total & [n] \\
\hline \multirow[t]{3}{*}{ Degree of urbanisation } & Densely populated & 7 & 65 & 13 & 15 & 100 & [5094] & 3 & 61 & 18 & 18 & 100 & [4410] \\
\hline & Intermediate & 7 & 74 & 9 & 10 & 100 & [3198] & 6 & 80 & 8 & 6 & 100 & [4959] \\
\hline & Thinly populated & 6 & 84 & 3 & 7 & 100 & [1551] & 7 & 82 & 6 & 5 & 100 & [2810] \\
\hline \multirow[t]{4}{*}{ Dwelling type } & flat (building $\geq 10$ dwellings) & (4) & 37 & 26 & 33 & 100 & [593] & 5 & 54 & 21 & 20 & 100 & [2442] \\
\hline & flat (building $<10$ dwellings) & 7 & 46 & 23 & 24 & 100 & [1137] & 6 & 68 & 14 & 12 & 100 & [4603] \\
\hline & semi-detached house & 8 & 72 & 9 & 11 & 100 & [5685] & 3 & 89 & (3) & 5 & 100 & [1945] \\
\hline & detached house $^{+}$ & 3 & 91 & $(2)$ & 4 & 100 & [2428] & 4 & 91 & $(2)$ & 3 & 100 & [3189] \\
\hline \multirow[t]{2}{*}{ Accessibility to public transport } & Easily & 7 & 70 & 11 & 12 & 100 & [8086] & 4 & 70 & 13 & 13 & 100 & [9462] \\
\hline & With difficulty & 7 & 71 & 8 & 14 & 100 & [1757] & 7 & 82 & 7 & 4 & 100 & [2717] \\
\hline \multirow[t]{4}{*}{ Tenure status } & Outright owner & 2 & 82 & 5 & 11 & 100 & [3443] & 2 & 90 & 3 & 5 & 100 & [3481] \\
\hline & Owner paying mortgage & 6 & 89 & 2 & 3 & 100 & [2980] & 4 & 91 & $(1)$ & 4 & 100 & [2842] \\
\hline & Rent at market rate & 11 & 53 & 20 & 16 & 100 & [1264] & 7 & 58 & 18 & 17 & 100 & [4917] \\
\hline & Rented at reduced rate/free & 12 & 35 & 27 & 26 & 100 & {$[2156]$} & 6 & 57 & 24 & 13 & 100 & [939] \\
\hline
\end{tabular}

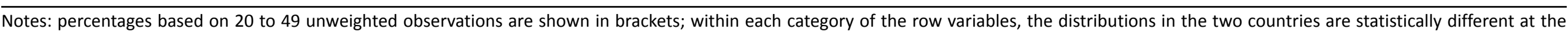

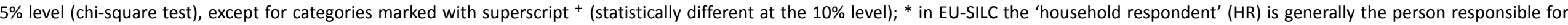
the accommodation. 
Table 2. Parameter estimates for the logistic regression for the probability of FCO (EU-SILC, 2012).

\begin{tabular}{|c|c|c|c|c|c|c|c|c|c|}
\hline \multirow{5}{*}{ Variable (reference category) } & \multirow{2}{*}{$\begin{array}{r}\text { Country } \\
\text { Model }\end{array}$} & \multicolumn{4}{|c|}{ UK } & \multicolumn{4}{|c|}{ Germany } \\
\hline & & \multicolumn{2}{|c|}{ Model 1} & \multicolumn{2}{|c|}{ Model 2} & \multicolumn{2}{|c|}{ Model 3} & \multicolumn{2}{|c|}{ Model 4} \\
\hline & Outcome & \multicolumn{2}{|c|}{ FCO } & \multicolumn{2}{|c|}{ FCO } & \multicolumn{2}{|c|}{ FCO } & \multicolumn{2}{|c|}{ FCO } \\
\hline & Base outcome & \multicolumn{2}{|c|}{ Rest of the sample } & \multicolumn{2}{|c|}{ CD } & \multicolumn{2}{|c|}{ Rest of the sample } & \multicolumn{2}{|c|}{ CD } \\
\hline & Level & Coeff. & Std. Err. & Coeff. & Std. Err. & Coeff. & Std. Err. & Coeff. & Std. Err. \\
\hline \multirow[t]{3}{*}{ Household size (ref. cat.: 1 ) } & 2 & 0.191 & 0.153 & $0.741^{* * *}$ & 0.199 & -0.075 & 0.135 & $0.618^{* * *}$ & 0.176 \\
\hline & 3 & 0.183 & 0.208 & $0.807^{* * *}$ & 0.280 & 0.041 & 0.223 & $1.188^{* * *}$ & 0.290 \\
\hline & $4+$ & 0.148 & 0.226 & $1.056 * * *$ & 0.295 & -0.292 & 0.267 & $1.241 * * *$ & 0.388 \\
\hline Minors (ref. cat.: 0) & $1+$ & $0.352^{* *}$ & 0.165 & $0.432^{*}$ & 0.241 & 0.192 & 0.199 & 0.107 & 0.271 \\
\hline \multirow{4}{*}{$\begin{array}{l}\text { Work intensity } \\
\text { (ref. cat.: Jobless household) }\end{array}$} & Low WI (0-0.5) & $0.531 * * *$ & 0.188 & $0.514^{* *}$ & 0.224 & $0.417^{*}$ & 0.214 & $0.691^{* *}$ & 0.269 \\
\hline & Medium WI (0.5-1) & 0.282 & 0.179 & $1.111^{* * *}$ & 0.216 & -0.082 & 0.190 & $0.620 * * *$ & 0.231 \\
\hline & High WI (1) & $0.321^{*}$ & 0.177 & $0.864^{* * *}$ & 0.238 & 0.184 & 0.189 & $0.876^{* * *}$ & 0.251 \\
\hline & No working age member & -0.176 & 0.268 & 0.483 & 0.370 & $-0.430^{*}$ & 0.256 & -0.083 & 0.298 \\
\hline \multirow{5}{*}{$\begin{array}{l}\text { Age of HR } \\
\text { (ref. cat.: 16-29) }\end{array}$} & $30-39$ & $0.419 * *$ & 0.204 & $0.661 * * *$ & 0.240 & 0.277 & 0.243 & 0.030 & 0.293 \\
\hline & $40-49$ & $0.496^{* *}$ & 0.204 & $0.988^{* * *}$ & 0.237 & $0.431^{*}$ & 0.233 & 0.271 & 0.283 \\
\hline & 50-59 & $0.546^{* *}$ & 0.219 & $1.280^{* * *}$ & 0.279 & $0.400^{*}$ & 0.226 & 0.302 & 0.288 \\
\hline & $60-69$ & 0.406 & 0.289 & $0.780^{* *}$ & 0.389 & 0.152 & 0.265 & 0.388 & 0.323 \\
\hline & $70+$ & -0.569 & 0.389 & 0.129 & 0.456 & -0.144 & 0.314 & 0.193 & 0.375 \\
\hline $\begin{array}{l}\text { No of members with health-related } \\
\text { activity limitations (ref. cat.: None) }\end{array}$ & $1+$ & $0.985^{* * *}$ & 0.113 & $0.514^{* * *}$ & 0.155 & $0.595^{* * *}$ & 0.113 & 0.232 & 0.150 \\
\hline Immigration status of HR (ref. cat.: No) & Yes & $0.289^{* *}$ & 0.144 & 0.091 & 0.191 & 0.140 & 0.202 & -0.192 & 0.249 \\
\hline Sex of HR (ref. cat.: Male) & Female & -0.104 & 0.101 & $-0.734 * * *$ & 0.151 & $0.260 * *$ & 0.106 & -0.175 & 0.140 \\
\hline \multirow{3}{*}{$\begin{array}{l}\text { Equivalised disposable income } \\
\text { quintile (ref. cat.: lowest) }\end{array}$} & Second & -0.148 & 0.126 & $0.332 * *$ & 0.169 & -0.082 & 0.132 & $0.435^{* * *}$ & 0.167 \\
\hline & Third & $-0.626^{* * *}$ & 0.142 & $0.359^{*}$ & 0.212 & $-0.900 * * *$ & 0.168 & $0.395^{*}$ & 0.220 \\
\hline & Fourth or highest & $-1.754^{* * *}$ & 0.183 & 0.419 & 0.257 & $-1.899 * * *$ & 0.201 & $0.984 * * *$ & 0.297 \\
\hline Degree of urbanisation (ref. cat.: & Intermediate & 0.027 & 0.108 & $0.376^{* *}$ & 0.151 & $0.723 * * *$ & 0.131 & $1.151^{* * *}$ & 0.158 \\
\hline Densely populated) & Thinly populated & 0.135 & 0.150 & $1.201 * * *$ & 0.253 & $0.804^{* * *}$ & 0.152 & $1.311 * * *$ & 0.204 \\
\hline
\end{tabular}


Table 2. Parameter estimates for the logistic regression for the probability of FCO (EU-SILC, 2012). (Cont.)

\begin{tabular}{|c|c|c|c|c|c|c|c|c|c|}
\hline \multirow[b]{5}{*}{ Variable (reference category) } & \multirow{2}{*}{$\begin{array}{r}\text { Country } \\
\text { Model }\end{array}$} & \multicolumn{4}{|c|}{ UK } & \multicolumn{4}{|c|}{ Germany } \\
\hline & & \multicolumn{2}{|c|}{ Model 1} & \multicolumn{2}{|c|}{ Model 2} & \multicolumn{2}{|c|}{ Model 3} & \multicolumn{2}{|c|}{ Model 4} \\
\hline & Outcome & \multicolumn{2}{|c|}{ FCO } & \multicolumn{2}{|c|}{ FCO } & \multicolumn{2}{|c|}{ FCO } & \multicolumn{2}{|c|}{ FCO } \\
\hline & Base outcome & \multicolumn{2}{|c|}{ Rest of the sample } & \multicolumn{2}{|c|}{ CD } & \multicolumn{2}{|c|}{ Rest of the sample } & \multicolumn{2}{|c|}{ CD } \\
\hline & Level & Coeff. & Std. Err. & Coeff. & Std. Err. & Coeff. & Std. Err. & Coeff. & Std. Err. \\
\hline \multirow{3}{*}{$\begin{array}{l}\text { Dwelling type (ref. cat.: flat } \\
\text { (building } \geq 10 \text { dwellings)) }\end{array}$} & Flat (building $<10$ dwellings) & $0.639^{* *}$ & 0.288 & $0.825^{* * *}$ & 0.319 & $0.231^{*}$ & 0.135 & $0.377^{* *}$ & 0.154 \\
\hline & Semi-detached house & $1.140 * * *$ & 0.269 & $1.519 * * *$ & 0.297 & 0.205 & 0.226 & 0.369 & 0.354 \\
\hline & Detached house & $0.547^{*}$ & 0.312 & $1.992 * * *$ & 0.403 & 0.141 & 0.211 & $0.511^{*}$ & 0.301 \\
\hline $\begin{array}{l}\text { Accessibility to public transport } \\
\text { (ref. cat.: Easily) }\end{array}$ & With difficulty & 0.200 & 0.127 & 0.218 & 0.191 & $0.317^{* *}$ & 0.123 & $0.370^{* *}$ & 0.185 \\
\hline \multirow{4}{*}{ Tenure status (ref. cat.: Outright owner) } & Owner paying mortgage & $0.692 * * *$ & 0.192 & $1.344 * * *$ & 0.305 & $0.567 * * *$ & 0.186 & $0.800 * *$ & 0.367 \\
\hline & Rent at market rate & $1.274 * * *$ & 0.208 & -0.018 & 0.284 & $0.899 * * *$ & 0.191 & -0.368 & 0.293 \\
\hline & Rent at reduced rate/free & $1.138 * * *$ & 0.186 & -0.005 & 0.262 & $0.581^{* *}$ & 0.231 & $-0.559^{*}$ & 0.330 \\
\hline & Constant & $-4.939 * * *$ & 0.382 & $-4.240 * * *$ & 0.454 & $-4.245^{* * *}$ & 0.328 & $-2.719 * * *$ & 0.423 \\
\hline McFadden's Pseudo $\mathrm{R}^{2}$ & & \multicolumn{2}{|c|}{0.17} & \multicolumn{2}{|c|}{0.26} & \multicolumn{2}{|c|}{0.13} & \multicolumn{2}{|c|}{0.23} \\
\hline $\bar{N}$ & & \multicolumn{2}{|c|}{9,843} & \multicolumn{2}{|c|}{1,699} & \multicolumn{2}{|c|}{12,179} & \multicolumn{2}{|c|}{1,577} \\
\hline
\end{tabular}


The logistic regression Models 2 and 4 (in Table 2) model the probability of belonging to FCO, rather than the 'Car Deprived' group. The goal here is to identify factors that might lead households struggling to afford the costs of motoring to buy and use cars, despite having to curtail expenditure in other essential areas. The goodness of fit for these models is higher than for Models 1 and 3 , suggesting that in both countries FCO differ more from $C D$ than from the average of the population. A complementary explanation is that the model picks up the factors associated with car ownership, controlling for material deprivation (note that roughly $70 \%$ of $C D$ households in both countries are materially deprived).

In both countries, the models show a positive association between household size and the probability of FCO. This is in contrast with Models 1 and 3, where the coefficients are insignificant. This suggests that FCO households are not larger than the average household, once other factors are controlled for, but they are larger than CD households. Work intensity and income also increase the probability of $\mathrm{FCO}$, as compared to $\mathrm{CD}$, although in the UK the probability peaks for households with 'medium' work intensity. A similar pattern is observed for income, with the highest coefficient values for households in the second and third quintile of the distribution. With regard to spatial factors, in both countries lower levels of urbanization and detached housing increase the relative probability of FCO.

Models 2 and 4 also highlight a number of differences between the two countries. In the UK, the relative probability of FCO, as compared to CD, is higher in the middle age bands, peaking for household respondents in their fifties, but no significant age effect is observed for Germany. Mobility difficulties and a male household respondent increase the relative probability of FCO in the UK, but not in Germany. Conversely, difficult access to public transport significantly increases the odds of being FCO (rather than $\mathrm{CD}$ ) in Germany only.

It is interesting to note the differences in coefficient values between Models 2 and 4, on one hand, and Models 1 and 3 . In both countries, the results suggest that FCO are typically poorer, less employed, and more likely to rent than the average of the population. However, they are typically richer, more likely to be employed, and to have mortgages than $C D$.

Having looked at the social and spatial factors associated with FCO, in the next section we sketch the profile of 'forced car owners' in terms of social exclusion.

\subsection{Social Exclusion, Material Deprivation, Economic Stress and Indebtedness among FCO}

Table 3 shows how the groups identified by the 'car ownership/material deprivation' indicator compare with respect to the indicators of social exclusion and economic stress defined in Section 3.3.2. Values for the full national samples (in the rightmost column) are very similar in the two countries confirming that they are well-suited for comparison. The exception is higher rates of housing cost overburden in Germany, which has a greater proportion of home-renters.

Unsurprisingly, for most indicators, 'Car Deprived' households show the highest, and 'Other Car Owners' the lowest values. FCO rank second to CD on most indicators, yet in both countries approximately $60 \%$ of FCO are AROPE, $30 \%$ are in 'severe' material deprivation, and $30-40 \%$ are income poor. While only approximately $20 \%$ of FCO are jobless in the two countries, the prevalence of low work intensity and in-work poverty is higher for FCO than CD. In both countries more than $60 \%$ of FCO can be considered 'fuel poor', with values considerably higher than any of the other groups. The percentage of FCO reporting 'housing cost overburden' is also higher than the population average, and close to the values observed for CD households.

Table 4 provides more detail into material deprivation, showing 'deprivation rates' (i.e., the percentage of households to whom the item applies) for each necessity covered by the indicator. For the purpose of this table, we compare FCO (which, by definition, are materially deprived) with materially deprived (MD) households who do not own cars (regardless of reasons for non-car ownership). A priori, we would expect FCO households to be better off than the comparison group, as in both countries they have higher average income (shown in the last row), although this is still much lower than for the full national sample.

As expected, levels of 'enforced lack of durables' are much lower among FCO-in both countries, only approximately one in twenty FCO households cannot afford one or more durables (other than the car), as compared to ca. $20 \%$ among other materially deprived households. However, levels of 'economic strain' are very similar in the two groups, and sometimes even higher among FCO.

In both countries, more than $90 \%$ of FCO are unable to face unexpected expenses or to pay for a week annual holiday. 20 to $50 \%$ of FCO in the UK also report arrears on payments. Notably, in both countries the proportion of household reporting arrears on 'hire purchase instalments or other loan payments' is higher among FCO than among other materially deprived households (note that the item covers all types of commercial credits including loans for the purchase of cars). The second-to-lastrow of the table presents complementary information on this type of debt, showing the percentage of households agreeing that it constitutes a burden for them: in both countries, this percentage is substantially higher among FCO, and particularly so in the UK where virtually one in two households find this debt to be burdensome.

Finally, the results confirm the finding of high levels of fuel poverty among FCO: in both countries, virtually half of them cannot afford to keep home warm, and in the UK more than $50 \%$ of FCO are in arrears on utility bills. 
Table 3. Indicators of social exclusion and economic stress: incidence among the groups (percentage values).

\begin{tabular}{lcccccccccc}
\hline & \multicolumn{4}{c}{ UK } & \multicolumn{3}{c}{ Germany } \\
\cline { 2 - 13 } & FCO & OCO & CD & ONCO & Full sample & FCO & OCO & CD & ONCO & Full sample \\
\hline $\begin{array}{l}\text { At risk of poverty or social } \\
\text { exclusion (AROPE) }\end{array}$ & 60 & 14 & 69 & 38 & 26 & 62 & 12 & 75 & 35 & 25 \\
\hline Severe material deprivation & 34 & - & 45 & 5 & 8 & 29 & - & 40 & $(4)$ & 6 \\
\hline Income poor & 31 & 11 & 42 & 23 & 17 & 41 & 10 & 63 & 31 & 20 \\
\hline Jobless household & 18 & 4 & 32 & 20 & 10 & 19 & 4 & 33 & 14 & 9 \\
\hline Low work intensity (0-0.5) & 16 & 4 & 13 & 6 & 6 & 12 & 4 & 6 & $(4)$ & 5 \\
\hline Working poor & 19 & 5 & 14 & 7 & 7 & 19 & 5 & 13 & 7 & 7 \\
\hline Fuel poverty & 79 & 15 & 49 & 22 & 23 & 66 & 12 & 36 & 19 & 19 \\
\hline Housing cost overburden & 13 & 5 & 19 & 12 & 8 & 35 & 15 & 44 & 31 & 21 \\
\hline
\end{tabular}

Note: percentages based on 20 to 49 unweighted observations are shown in brackets.

Table 4. Material deprivation, perceived burden of debt, and income for FCO and other materially deprived households (percentage values, income in local currency).

\begin{tabular}{|c|c|c|c|c|c|c|}
\hline & \multicolumn{3}{|c|}{ UK } & \multicolumn{3}{|c|}{ Germany } \\
\hline & FCO & $\begin{array}{l}\text { MD, } \\
\text { no car }\end{array}$ & $\begin{array}{l}\text { Full } \\
\text { sample }\end{array}$ & FCO & $\begin{array}{l}\text { MD, } \\
\text { no car }\end{array}$ & $\begin{array}{c}\text { Full } \\
\text { sample }\end{array}$ \\
\hline Cannot afford to face unexpected financial expenses & 99 & 99 & 41 & 97 & 98 & 37 \\
\hline $\begin{array}{l}\text { Cannot afford one week annual holiday away } \\
\text { from home }\end{array}$ & 91 & 92 & 28 & 91 & 94 & 24 \\
\hline Unpaid arrears on mortgage or rent payments & 26 & 27 & 3 & 12 & 11 & 2 \\
\hline Unpaid arrears on utility bills & 51 & 57 & 8 & 19 & 21 & 3 \\
\hline $\begin{array}{l}\text { Unpaid arrears on hire purchase instalments or } \\
\text { other loan payments }\end{array}$ & 19 & 13 & 2 & 10 & (6) & 1 \\
\hline $\begin{array}{l}\text { Cannot afford a meal with meat, chicken, fish } \\
\text { (or vegetarian equivalent) every second day }\end{array}$ & 47 & 53 & 9 & 69 & 71 & 10 \\
\hline Cannot afford to keep home adequately warm & 46 & 46 & 8 & 44 & 36 & 5 \\
\hline $\begin{array}{l}\text { Cannot afford at least one among: washing machine, } \\
\text { colour TV, telephone }\end{array}$ & (4) & 17 & 2 & (5) & 22 & 2 \\
\hline Cannot afford a car/van for private use & - & 72 & 11 & - & 80 & 11 \\
\hline $\begin{array}{l}\text { Repayment of debts from hire purchases or } \\
\text { loans is 'somewhat' or a 'heavy' burden }\end{array}$ & 49 & 29 & 23 & 32 & 15 & 17 \\
\hline Average equivalised disposable income & 14,772 & 11,723 & 22,206 & 13,930 & 10,035 & 21,332 \\
\hline
\end{tabular}

Note: estimates based on 20 to 49 unweighted observations are shown in brackets.

\section{Discussion and Conclusions}

Several messages can be drawn from our analysis. First, in both countries the socio-demographic profile of FCO deviates in a number of respects from that of 'car deprived' households, and from the recurrent characters of transport and social exclusion research. FCO are relatively more likely to include children and employed adults in the middle age groups, to be on low-to-middle incomes and to have a mortgage. This profile is consis- tent with previous research from Australia, suggesting that in developed countries FCO tends to affect similar households-although the finding that FCO often have only low levels of work intensity suggests a potential new direction for future research.

Second, our analysis shows contrasting spatial patterns of FCO between Germany-with higher incidence in rural areas, and for those with difficult access to public transport-and the UK-with similar incidence in urban and rural areas, and across levels of public transport ac- 
cessibility. The UK situation contrasts with previous research, which has tended to see FCO as an eminently suburban or rural problem (see Curl et al., in press, for an exception). There are three possible explanations for this finding. First, it must be noted that the 'degree of urbanisation' variable employed here is defined at the municipality level, meaning that certain lower-density suburban areas can be classified as 'dense areas', as long as more than $50 \%$ of the population in the municipality resides in a high density cluster. Second, unlike Australia and most continental EU, in the UK deprivation is relatively concentrated in inner cities and urban areas (Eurostat, 2015), and this tends to offset the 'spatial gradient' of FCO (Mattioli \& Colleoni, 2016; Mattioli et al., 2017). Finally, the lack of a 'public transport accessibility effect' in the UK may be linked to the deterioration of public transport quality and service levels post-deregulation. As noted above, the accessibility variable used here is best interpreted as measure of access to public transport stops. If public transport services are poor quality and expensive, even those with easy access to stops may be 'forced' into car ownership. This may be particularly true for low-income households if the transit network is not sufficiently suited to their commuting patterns, particularly in suburban areas.

Overall, however, our analysis shows remarkable similarities between the two countries with regard to incidence and socio-demographic patterns of FCO, and this is also broadly true for levels of social exclusion and economic stress. Thanks to the richness of EU-SILC, we have provided a more detailed picture of the possible impacts of FCO than previous research. We find that FCO have lower overall levels of social exclusion and material deprivation than households who cannot afford cars. This, and the fact that FCO have higher incomes, are more likely to be employed and to have mortgages than $C D$, could be used to argue that their car ownership is not really 'forced' but rather the result of 'choice'. However, our analysis also shows that FCO are worse off than CD in a number of domains, including in-work poverty and fuel poverty. While enforced lack of durables is very rare among FCO, their levels of economic strain are very close to those of other materially deprived households, and this despite higher incomes. This may suggest that the possession and use of an expensive durable such as the car (whether 'enforced' or not) can result in deprivation and economic stress for households with limited resources. Notably, we find suggestive evidence that FCO may forego spending on home heating to afford car use, although demonstrating a direct link between the two will require further research.

Also, our findings are suggestive of a relationship between FCO and household debt. FCO are relatively likely to have unpaid arrears, including possibly for car loans. They are also more likely than other households to report burdensome levels of debt from hire purchases or loans, with this being more pronounced in the UK. This dovetails with the recent findings of Walks (in press), who has found a positive relationship between levels of car dependence and household debt burdens, notably for car loans, among low-income households in Canadian city regions. Our results also show that FCO households are more likely than $C D$ to carry mortgages, and less likely to rent at reduced rates. One possible interpretation is that, for many FCO households, slightly higher income levels mean that they cannot qualify for social or subsidized housing, and thus have to find accommodation in the private market, which often means taking up debt in the form of mortgages. Overall, our findings confirm that the links between FCO and the financialization of the housing and automobile markets is a promising area for future research.

With regard to policy implications, previous research has emphasised the need for compact city development and improved public transport provision, in order to reduce the need for car ownership and use (e.g., Currie \& Senbergs, 2007; Dodson \& Sipe, 2008). These points remain important, and our analysis provides further evidence to support them. On the other hand, our findings suggest that, at least for some, the achievement of (partial) inclusion in the employment and housing domain depends on expensive (and potentially unaffordable) car ownership and use. At the same time, FCO may result in households foregoing expenditure on other important necessities (e.g., home heating) and carrying burdensome levels of debt. Overall this calls for more joinedup policy thinking to ensure that social inclusion in key areas, including transport, is not achieved off the back of 'hidden' forms of economic stress, material deprivation and indebtedness. This suggests that initiatives in non-spatial, non-transport areas of policy-making (such as housing, employment, welfare, and credit regulations) may have role to play in mitigating the FCO problem. These may be particularly relevant in countries such as the UK, where FCO does not appear to be an exclusively rural or periurban issue.

To conclude, this article has demonstrated how the concept of FCO can be operationalised using EU-SILC data. This data has been collected since 2004, and includes more than 28 countries. This opens up a number of research opportunities which go beyond what presented here. It makes it possible to conduct comparative research on e.g. how the 2008 economic crisis and its aftermath have impacted on levels and patterns of FCO in countries with different levels of GDP, motorisation, and trajectories of development. Also, EU-SILC includes a longitudinal component, and this could be used to investigate the effect of life events (including changes in economic circumstances) on transitions to/from FCO and 'car deprivation'.

\section{Acknowledgements}

This work arises from the research project "Energyrelated economic stress in the UK, at the interface between transport, housing and fuel poverty", funded by 
the Engineering and Physical Sciences Research Council (grant number EP/M008096/1) as part of the RCUK Energy Programme. It is based on data from Eurostat, EUSILC, 2012. The responsibility for the analysis, interpretation and all conclusions drawn from the data lies entirely with the author. The funders had no involvement in the analysis and interpretation of the data, nor in the writing and submission of the article.

\section{Conflict of Interests}

The author declares no conflict of interests.

\section{References}

Baing, A. S. (2010). Containing urban sprawl? Comparing brownfield reuse policies in England and Germany. International Planning Studies, 15(1), 25-35.

Banister, D. (1994). Internalising the social costs of transport. Paris: OECD/ECMT Seminar.

Belton Chevallier, L., Fol, S., Motte-Baumvol, B., \& Jouffe, Y. (in press). Coping with car dependency: A system of expedients used by low-income households on the outskirts of Dijon and Paris. Transport Policy.

Berry, A., Jouffe, Y., Coulombel, N., \& Guivarch, C. (2016). Investigating fuel poverty in the transport sector: Toward a composite indicator of vulnerability. Energy Research \& Social Science, 18, 7-20.

BMVBS (2012). Mobilität, Erreichbarkeit und soziale Exklusion. Fähigkeiten und Ressourcen einer ländlichen Bevölkerung für eine angemessene Versorgung und Teilhabe am öffentlichen Leben. BBSR-OnlinePublikation 27/2012. Bonn: BBSR.

Cao, M., \& Hickman, R. (in press). Car dependence and housing affordability: An emerging social deprivation issue in London? Urban Studies.

Curl, A., Clark, J., \& Kearns, A. (in press). Household car adoption and financial distress in deprived urban communities: A case of forced car ownership? Transport Policy.

Curl, A., Nelson, J. D., \& Anable, J. (2011). Does accessibility planning address what matters? A review of current practice and practitioner perspectives. Research in Transportation Business \& Management, 2, 3-11.

Currie, G. (Ed.). (2011). New perspectives and methods in transport and social exclusion research. Bingley: Emerald.

Currie, G., \& Delbosc, A. (2011). Mobility vs. affordability as motivations for car-ownership choice in urban fringe, low-income Australia. In K. Lucas, E. Blumenberg, \& R. Weinberger (Eds.), Auto motives: Understanding car use behaviours. Bingley: Emerald.

Currie, G., \& Senbergs, Z. (2007). Exploring forced car ownership in metropolitan Melbourne. Paper presented at the Australasian Transport Research Forum 2007.

Currie, G., Stanley, J., \& Stanley, J. (2007). No way to go: Transport and social disadvantage in Australian com- munities. Clayton: Monash University ePress.

Dodson, J., \& Sipe, N. (2008). Shocking the suburbs: Urban location, homeownership and oil vulnerability in the Australian city. Housing Studies, 23(3), 377-401.

Dziekan, K. (2011). Öffentlicher Verkehr. In O. Schwedes (Ed.), Verkehrspolitik. Wiesbaden: Springer.

Eurostat. (n.d.). The new degree of urbanisation. Eurostat. Retrieved from http://ec.europa.eu/eurostat/ ramon/documents/DEGURBA/DEGURBA_Methodo logy_DG_REGIO.zip

Eurostat. (2015). Quality of life by degree of urbanisation. Eurostat. Retrieved from http://ec.europa.eu/ eurostat/statistics-explained/index.php/Quality_of_ life_by_degree_of_urbanisation

Eurostat. (2017). Statistics explained. Eurostat. Retrieved from http://ec.europa.eu/eurostat/statisticsexplained

Fusco, A., Guio, A.-C., \& Marlier, E. (2013). Building a material deprivation index in a multinational context: Lessons from the EU experience. In V. Berenger \& F. Bresson (Eds.), Poverty and social exclusion around the Mediterranean Sea (pp. 43-71). New York: Springer.

Gleeson, B., \& Randolph, B. (2002). Social disadvantage and planning in the Sidney context. Urban Policy and Research, 20(1), 101-107.

Jones, P. M. (1987). Mobility and the individual in western industrial society. In P. Nijkamp \& S. Reichman (Eds.), Transportation planning in a changing world. Aldershot: Gower.

Li, T., Dodson, J., \& Sipe, N. (in press). Examining household relocation pressures from rising transport and housing costs: An Australian case study. Transport Policy.

Logemann, J. L. (2012). Trams or tailfins? Public and private prosperity in postwar West Germany and the United States. University of Chicago Press.

Lucas, K. (2012). Transport and social exclusion: Where are we now? Transport Policy, 20, 105-113.

Lucas, K., Bates, J., Moore, J., \& Carrasco, J. A. (2016). Modelling the relationship between travel behaviours and social disadvantage. Transportation Research Part $A, 85,157-173$.

Mattioli, G. (2013). Where sustainable transport and social exclusion meet: Households without cars and car dependence in Germany and Great Britain (unpublished PhD thesis). Department of Sociology and Social Research, University of Milan-Bicocca, Milan.

Mattioli, G. (2014). Where sustainable transport and social exclusion meet: Households without cars and car dependence in Great Britain. Journal of Environmental Policy \& Planning, 16(3), 379-400.

Mattioli, G. (2015). Energy-related economic stress at the interface between transport, housing and fuel poverty: A multinational study. In Second International Research Days of the Sociology of Energy (pp. 254-257).

Mattioli, G. (2016). Transport needs in a climate- 
constrained world. A novel framework to reconcile social and environmental sustainability in transport. Energy Research \& Social Science, 18, 118-128.

Mattioli, G., \& Colleoni, M. (2016). Transport disadvantage, car dependence and urban form. In P. Pucci \& M. Colleoni (Eds.), Understanding mobilities for designing contemporary cities. Heidelberg: Springer.

Mattioli, G., Lucas, K., \& Marsden, G. (2017). Transport poverty and fuel poverty in the UK: From analogy to comparison. Transport Policy, 59, 93-105.

Mees, P. (2010). Transport for suburbia: Beyond the automobile age. Earthscan.

Mullen, C., \& Marsden, G. (in press). The car as a safetynet: narrative accounts of the role of energy intensive transport in conditions of housing and employment uncertainty. In A. Hui, G. Walker, \& R. Day (Eds.), Demanding energy: Space, time and change. Palgrave Macmillan: Hampshire.

Ortar, N. (in press). Dealing with energy crises: Working and living arrangements in peri-urban France. Transport Policy.

Ponthieux, S. (2010). Assessing and analysing in-work poverty risk. In A. B. Atkinson \& E. Marlier (Eds.), Income and living conditions in Europe. Luxembourg: Publication Office of the European Union.

Pooley, C. (2016). Mobility, transport and social inclusion: Lessons from history. Social Inclusion, 4(3), 100-109.

Preston, J., \& Almutairi, T. (2013). Evaluating the long term impacts of transport policy: An initial assess- ment of bus deregulation. Research in Transportation Economics, 39(1), 208-214.

Pucher, J., \& Kurth, S. (1996). Verkehrsverbund: The success of regional public transport in Germany, Austria and Switzerland. Transport Policy, 2(4), 279-291.

Ricci, M., Parkhurst, G., \& Jain, J. (2016). Transport policy and social inclusion. Social Inclusion, 4(3), 1-6.

Scheiner, J. (in press). Transport costs seen through the lens of residential self-selection and mobility biographies. Transport Policy.

SEU. (2003). Making the connections: Final report on transport and social exclusion. London: Office of the Deputy Prime Minister.

Shaw, J., \& Docherty, I. (2014). The transport debate. Bristol: Policy Press.

Stokes, G., Lucas, K. (2011). National travel survey analysis. Working Paper No. 1053. Oxford: University of Oxford Transport Studies Unit.

Thomson, H., \& Snell, C. (2013). Quantifying the prevalence of fuel poverty across the European Union. Energy Policy, 52, 563-572.

Walks, A. (2015). Driven into debt? Automobility and financial vulnerability. In A. Walks (Ed.), The urban political economy and ecology of automobility: Driving cities, driving inequality, driving politics. Routledge, Abingdon.

Walks, A. (in press). Driving the poor into debt? Automobile loans, transport disadvantage, and automobile dependence. Transport Policy.

\section{About the Author}

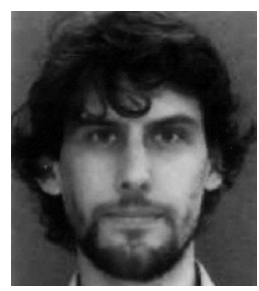

Giulio Mattioli is Research Fellow in Sustainable Transport at the Sustainability Research Institute and the Institute for Transport Studies, University of Leeds. He has a background in Sociology, Urban Studies and Transport Studies. He has researched issues concerning car dependence, transport disadvantage and affordability, recently leading the research project "Energy-related economic stress in the UK, at the interface between transport, housing and fuel poverty", linked to the DEMAND Research Centre (https://teresproject.wordpress.com). 